\title{
Spatial distribution and landscape characteristics of Flores Hawk-Eagle (Nisaetus Floris) habitat in Flores Island
}

\author{
Syartinilia $^{\mathrm{a}}$, Raja Mohd Kris Setiawan ${ }^{\mathrm{b}}$ \\ ${ }^{a}$ Department of Landscape Architecture, Faculty of Agriculture, IPB University, Kampus IPB Darmaga Bogor, 16680, Indonesia \\ [+62 251-8422415] \\ b PT Abyakta Bhumi Arya, Landscape Consultant, Tanah Baru, Kota Bogor, 16152, Indonesia
}

\section{Article Info:}

Received: 01 - 10 - 2021

Accepted: 03 - 11 - 2021

\section{Keywords: \\ Kernel density estimation minimum convex polygon, Nisaetus floris, patch habitat, principal component analysis \\ Corresponding Author: Syartinilia \\ Department of Landscape Architecture, Faculty of Agriculture, IPB University; Tel. +62-251-8422415 \\ Email: \\ syartinilia@apps.ipb.ac.id}

\begin{abstract}
The study on the endemic and keystone species Flores Hawk-Eagle (FHE, Nisaetus floris) is currently experiencing limited information for estimating their distribution area. The FHE habitat distribution is required as the essential information for developing the strategies and conservation action plan. The objectives of this study were to identify the spatial habitat distribution and analyze the characteristics of the habitat. Minimum convex polygon (MCP) and kernel-density estimation (KDE) 95\% was combined with the land cover map for delineating the patch habitat of FHE. Slope, elevation, and land cover were used as environmental variables. Principal Component Analysis (PCA) combine with GIS were used for characterizing the landscape habitat. The results showed that there were eight habitat patches with a total area of $1.132 \mathrm{~km}^{2}$. Six principal components were retained from PCA analysis which explained $71.96 \%$ of data variance. Habitat characteristics of FHE describe its requirement for nesting and hunting activities for principal components 1 to 4 , while for flight activity related to principal components 5 and 6. Forests and savannahs become the main habitat preference for both nesting and hunting activities. Results of this study will be supported as baseline information for developing conservation strategies and action for FHE.
\end{abstract}

How to cite (CSE Style $8^{\text {th }}$ Edition):

Syartinilia, Setiawan RMK. 2021. Spatial distribution and landscape characteristics of Flores Hawk-Eagle (Nisaetus Floris) habitat in Flores Island. JPSL 11(4): 542-549. http://dx.doi.org/10.29244/jpsl.11.4.542-549.

\section{INTRODUCTION}

The Flores Hawk-Eagle (FHE, Nisaetus floris, Hartert, 1898) is a raptor species endemic to the Lesser Sundas or the Nusa Tenggara Islands. The distribution area of this species is limited mainly in lowland forests to submontane (submontane) with an altitude of $1700 \mathrm{~m}$ above sea level (Coates and Bishop, 1997; FergusonLees and Christie, 2001; Raharjaningtrah and Rahman, 2004; Gjershaug et al., 2004). The main habitat is covered by primary and secondary forest vegetation (Raharjaningtrah and Rahman, 2004; Gjershaug et al., 2004). The FHE is a keystone species whose presence has a significant impact on ecosystem stability. According to the IUCN (International Union for Conservation of Nature), FHE is designated as Critically Endangered Red List since 2009 (BirdLife International, 2018) because its population is estimated not to exceed 250 individuals. In addition, FHE is designated as 25 priority species targeted for a population increase of 10\% in the Decree of the Director-General of PHKA Number: S.20/IV-KKH/2015 dated January 12, 2015. 
The distribution of the FHE population usually inhabits lowland forests and submontane forests up to an altitude of 1600 meters above sea level (masl). Approximately 100 pairs of FHE are found in lowland areas with $40 \mathrm{~km}^{2}$ in Flores. The distribution area is in the Mbeliling Forest Area and Kelimutu National Park. The Mbeliling Forest located on the island of Flores is one of the landscapes that still has the potential for endemic birds, including FHE. The existence of the FHE has been threatened by human activities such as poaching, logging, and land cover change activities (Suparman, 2012).

According to Raharjaningtrah and Rahman (2004), studies on the FHE have difficulties due to limited information to estimate their distribution area based on their habitat and territory behavior. In addition, the lack of information regarding the habitat characteristics of the Flores eagle adds to the difficulty in formulating a strategy and action plan for the Flores eagle conservation. Therefore, a study is required to identify the spatial distribution and landscape characteristics of the FHE habitat on the island of Flores. This study aimed to 1) identify the spatial distribution of the FHE habitat on Flores Island, 2) analyze the landscape characteristics of the FHE habitat on Flores Island.

\section{METHODS}

\section{Study Area and Time}

This study was conducted on Flores Island (Figure 1) consisting of seven districts and covered area of 14 $300 \mathrm{~km}^{2}$. Flores Island is located in East Nusa Tenggara Province, which is included in the Lesser Sunda Islands group along with Bali and NTB. The island is bordered by Lembata, Adonara, and Solor islands in the east, Komodo and Rinca islands in the west, the Sawu Sea in the south and Sulawesi in the north. There is a big national park area in Flores island: Kelimutu National Park, located in Ende District. It consists of a landscape with hills and mountains, with Mount Kelibara $(1731 \mathrm{~m})$ as its highest peak. Mount Kelimutu, which has the three coloured lakes, is also located in this national park. Most of the people of Flores come from the Manggarai tribe, most of whom can recognize many types of eagles. The Manggarai tribe in western Flores regards the Flores eagle as a toem or empo, the ancestor of humankind, and should not be tortured, killed, or captured (Trainor and Lesmana, 2000). Flores Island is mostly located in lowland areas with an altitude below 1000 meters asl with a hilly topography. The study was conducted from March 2016 to April 2017.

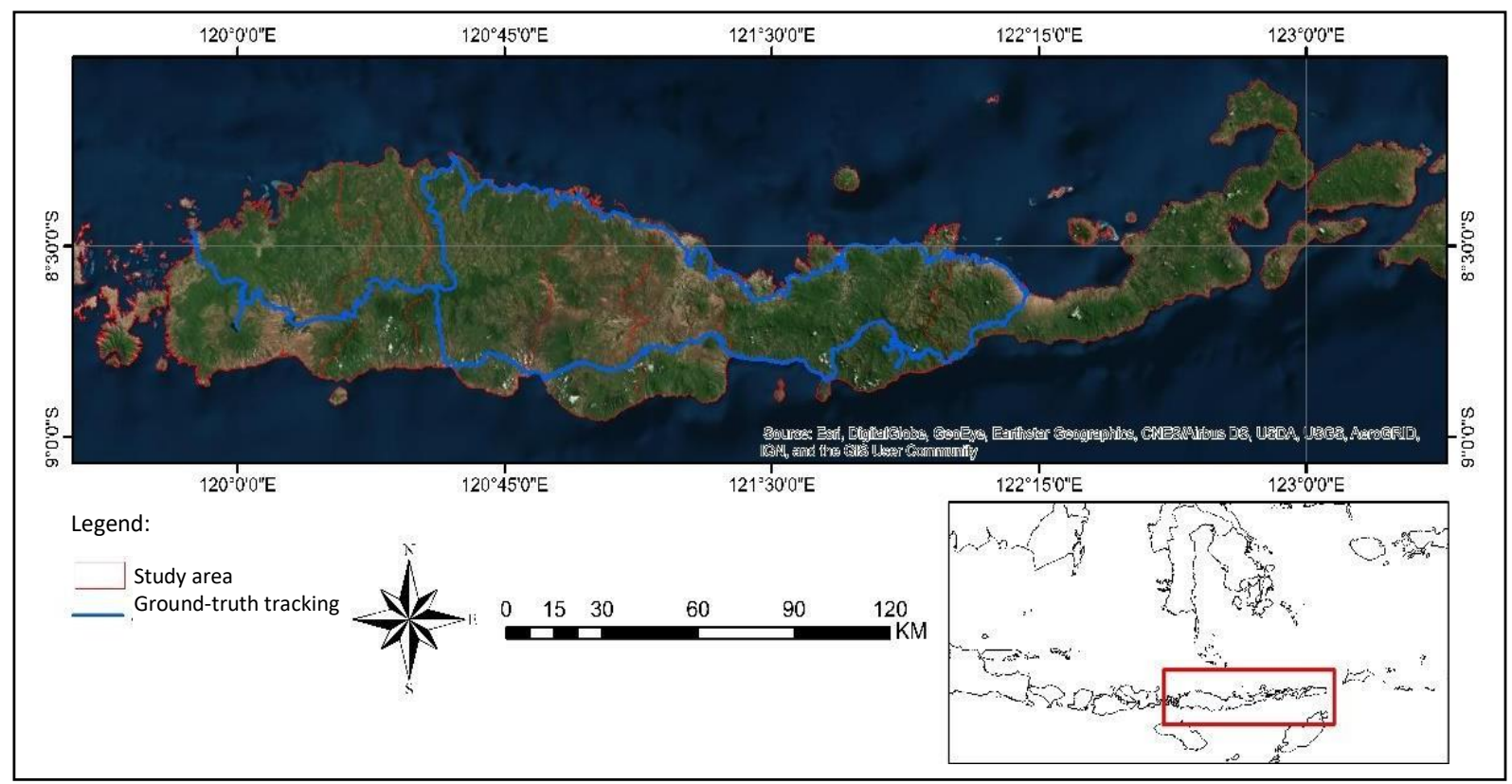

Figure 1 Study area

Source: Landsat 8 (November 2015) 


\section{Method of Data Collecting}

The data collection stage includes collecting spatial (raster and vector) and non-spatial (descriptive) data. The data includes Landsat 8 satellite images which is captured on November 2015 used to analyze land cover, while a DEM (Digital Elevation Model) from ASTERGDEM, $30 \mathrm{~m}$ resolution, analyses the slope and elevation. This stage also includes a ground truth check of locations that are the habitat for FHE. Direct observations, field documentation, and interviews with related parties, including communities, NGOs, and the national park managers, were carried out at the field survey stage. The spatial distribution of the existing FHE habitat at the encounter point location was carried out through a ground check. The observation location was determined by considering the results of identifying the distribution of the FHE and local survey data from the Kelimutu National Park Office and RCS (Raptor Conservation Society). Observations were made for 12 days (May 24 until June 7, 2016) starting at 07.00-17.00. Activities carried out during the ground-check include: (1) recording each geographic location of the encounter of the FHE nest point using GPS; (2) observing the landscape condition including vegetation, presence of other animals, water sources, topography, and altitude; and (3) record the activities of the FHE.

\section{Spatial Distribution Analysis}

This analysis used the minimum convex polygon (MCP) and kernel-density estimation (KDE) 95\% methods combined with land cover maps. The MCP method connects the outermost points of species distribution data to determine the home range or create a concentration area for distributing a data object or species (Kolodzinski et al., 2010). Determination of MCP from the results of field data collection and analysis aims to determine the area affected by the distribution of the FHE. At the same time, the KDE method is used to determine the minimum home range of the FHE. The points used to create polygons through MCP and KDE 95\% analysis obtained from FHE meeting locations are directly observed in the field and secondary data. This analysis uses Hawth's tools extension for ArcGIS 10.3. The polygons obtained from the MCP and KDE analyzes were then overlaid with forest cover to refine the outer boundary of the habitat patch. The delineation process uses Arcgis 10.3 software.

\section{Analysis of Landscape Characteristics}

The environmental variables used to analyze the landscape characteristics of the FHE habitat are slope, elevation, and land cover. It is assumed that the FHE tends the selection of a habitat based on the specific characters. Total 21 environmental variables were analyzed to characterized the landscape of the FHE habitat (Table 1).

Table 1 Environmental variables used

\begin{tabular}{|c|c|c|c|}
\hline No & $\begin{array}{l}\text { Environmental Variables } \\
\text { (Euclidean distance) }\end{array}$ & No & $\begin{array}{c}\text { Environmental Variables } \\
\text { (Euclidean distance) }\end{array}$ \\
\hline 1 & Elevation $0-300 \mathrm{~m}$ & 12 & Slope $25-45 \%$ \\
\hline 2 & Elevation $300-500 \mathrm{~m}$ & 13 & Slope $>45 \%$ \\
\hline 3 & Elevation $500-700 \mathrm{~m}$ & 14 & Water Bodies \\
\hline 4 & Elevation 700-1 $000 \mathrm{~m}$ & 15 & Forest \\
\hline 5 & Elevation $1000-1500 \mathrm{~m}$ & 16 & Orchard \\
\hline 6 & Elevation $1500-2000 \mathrm{~m}$ & 17 & Built-up \\
\hline 7 & Elevation $>2000 \mathrm{~m}$ & 18 & Savanna \\
\hline 8 & Slope $0-3 \%$ & 19 & Rice field \\
\hline 9 & Slope 3-8\% & 20 & Shrub \\
\hline 10 & Slope $8-15 \%$ & 21 & Open land \\
\hline & Slope $15-25 \%$ & & \\
\hline
\end{tabular}


The land cover map was produced by supervised classification using the 2014 ERDAS, divided into eight classes: water bodies, forest, orchard, built-up area, savanna, rice fields, shrub, and open land. Land cover, elevation, and slope maps are converted into a euclidean distance map that provides distance (meter) information from each raster cell to the nearest specified landscape characters. The landscape characteristics of the FHE habitat were analyzed in the grid size of $3.5 \mathrm{~km}^{2}$. The grid size is obtained based on the assumption of a minimum home range for each pair of FHE (Suparman, 2012). The total number of grids obtained is 155, and then the analyzed conduct in a grid with FHE encounters within the grid. In each grid, the value of environmental variables is extracted using ArcGIS 10.3. Principal Component Analysis (PCA) was carried out separately on environmental variables using SPSS 15. This analysis is used to determine the importance of environmental variables in each patch of the FHE habitat.

\section{RESULTS AND DISCUSSIONS}

\section{Spatial Distribution}

The spatial distribution of the FHE habitat (Figure 2) consists of eight spreading patches on the island of Flores, which covered $1132 \mathrm{~km}^{2}$ (Table 2). Based on the results of the overlay with land cover, elevation, and slope, it was found that FHE habitat patches were dominated by forest cover (47\%), 1 000-1 500 masl (29\%), and slope of $25-45 \%$ (35\%). This result is aligned with the prior studies that mention the FHE depends on lowland to submontane rain forests and forest mountains as high as $1600 \mathrm{~m}$ in Flores (Gjershaugh et al., 2004; Raharjaningtrah and Rahman, 2004). Meanwhile, based on protected areas, it is known that only $26 \%$ (298 $536 \mathrm{~km}^{2}$ ) located within the protected area. Habitat patches located in protected areas are only found in Ruteng Nature Park and Kelimutu National Park.

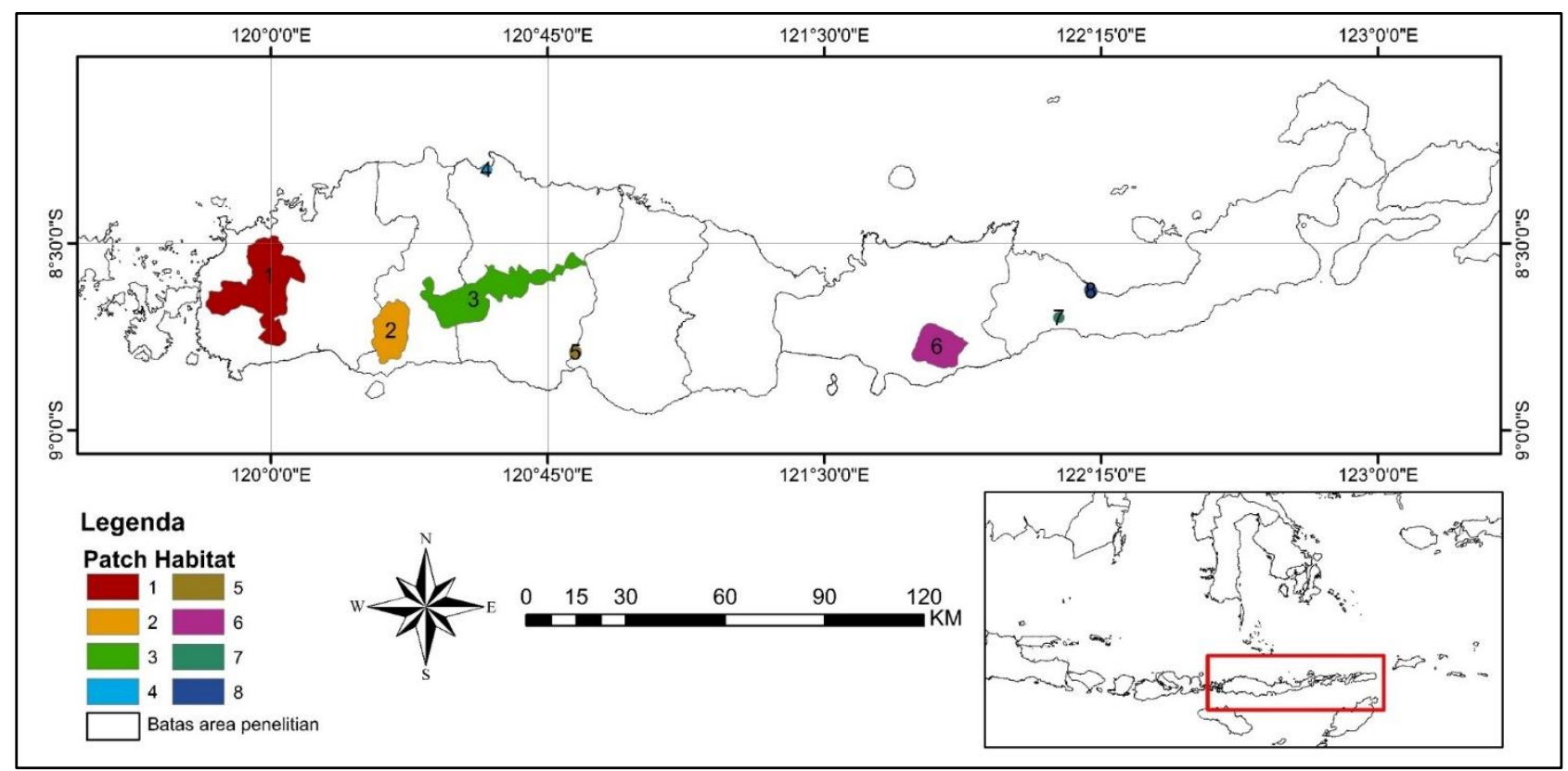

Figure 2 Spatial distribution of FHE habitat

Based on the field survey in Kelimutu Nationa Park, the trees that became the nests of JFE were in the customary forest of Wolujita Village, namely in two species of Pulai (Alstonia scholaris) and Sengon (Paraserianthes falcataria). In Kelimutu National Park, FHE habitats were found in the Wolojita Resort, with the secondary forest as a buffer zone for the Kelimutu National Park. The secondary forest was chosen because it has a slightly open forest canopy, making it easier for raptors to hunt for prey such as snakes, lizards, etc. Like other raptors, the FHE flies by dropping and soaring to a certain height and then gliding, and hunting activities are commonly carried out in open areas (Suparman, 2012). 
Table 2 Description of patch habitat

\begin{tabular}{|c|c|c|c|c|}
\hline \multirow{2}{*}{$\begin{array}{l}\text { Patch } \\
\text { Number }\end{array}$} & \multirow{2}{*}{ Location (Sub-District) } & \multirow{2}{*}{$\begin{array}{l}\text { Area } \\
\left(\mathrm{km}^{2}\right)\end{array}$} & \multicolumn{2}{|l|}{ Source } \\
\hline & & & Field Survey & RCS \\
\hline 1 & Komodo, Boleng, Sano Nggoang, Lembor & 428 & $\sqrt{ }$ & $\sqrt{ }$ \\
\hline 2 & Lembor, Satarmese, Ruteng & 159 & $\sqrt{ }$ & $\sqrt{ }$ \\
\hline 3 & $\begin{array}{l}\text { Satarmese, Ruteng, Kota komba, Riung Barat, Borong, } \\
\text { Elar, Sambi rampas, Poco ranaka, Wae rii, Langke } \\
\text { rembong }\end{array}$ & 356 & $\sqrt{ }$ & $\sqrt{ }$ \\
\hline 4 & Lamba lada & 11 & $\sqrt{ }$ & \\
\hline 5 & Kota Komba, Aimere & 8 & $\sqrt{ }$ & \\
\hline 6 & $\begin{array}{l}\text { Ndona, Ndona Timur, Wolujita, Detusoko, Woluwaru, } \\
\text { Kelimutu }\end{array}$ & 150 & $\sqrt{ }$ & \\
\hline 7 & Mego, Lela, Nita & 8 & $\sqrt{ }$ & \\
\hline 8 & Alok timur, Alok & 12 & $\sqrt{ }$ & \\
\hline & Total & 1132 & & \\
\hline
\end{tabular}

Note: Raptor Conservation Society (RCS)

\section{Landscape Characteristics}

Habitat characteristics of the FHE were obtained from interpretation of the Principal Component Analysis result, which retained six principal components (PC) have explained $71.96 \%$ of variance data (Table 3 ). The principal component value is formed based on the value of the variance and eigenvalue. The eigenvalue indicates the magnitude of the influence of data on the characteristics of the variables. At the same time, variance is the amount of data distribution on each variable. The first PC (PC1) indicated that FHE habitats were characterized by having an elevation 0-700 $\mathrm{m}$ asl and influenced by the orchard and built-up area. The second PC (PC2) is mainly influenced by having an elevation $>2000 \mathrm{~m}$ asl and the open land and orchard. The third PC (PC3) is mainly influenced by an elevation of 700-2 $000 \mathrm{~m}$ asl and shrub and water bodies. FHE uses the landscape characteristics of PC1-PC3 for crossing and other activities such as foraging characterized by vegetated areas such as orchards and shrubs.

The fourth PC (PC4) showed that FHE habitats were associated with particular slope $>45 \%$, forest, and savanna. These landscape characteristics are related to the needs of the Flores Eagle FHE for nesting and hunting. Based on Syartinilia and Tsuyuki (2008), the steep slope chosen by the Javan eagle is related to the safety factor of the nest from various disturbances. For nesting, FHE is looking for tall trees in the forest and has an abundance of food. Forests are the main hunting areas, and savanna is also an alternative hunting area because it has extensive grasslands with few trees. The savanna is giving an open view favourable to raptors such as the FHE for hunting their prey and the trees that are used to perch and watch on their prey. These characteristics are similar in migratory raptor oriental honey-buzzards (Pernis ptilorhynchus), which have wintering sites in Flores Island (Syartinilia et al., 2020). The branching form of the two nest tree species in Kelimutu National Park buffer area, namely Pulai (Alstonia scholaris) and Sengon (Paraserianthes falcataria), consists of at least three branches that support the placement of the FHE nest (Figure 3). These tree species are emergent trees located on steep slopes and face settlements. This character is also found in the Javan HawkEagle's preference for making nests in highland forests, namely in steep areas, and choosing emergent trees (Wells, 1985; van Balen et al., 2001; Syartinilia and Tsuyuki, 2008). The nest tree is located at an altitude of $392 \mathrm{~m}$ above sea level and has more than a 45\% slope. Following the Verhoeye and Holmes (1998), most FHE habitats are in lowland forests. The fifth and sixth PCs are associated with 0-15\% (PC5) and 15-45\% (PC6) slopes, indicating the need for slope variation in a landscape. 
Table 3 Principal Component Analysis (PCA) results

\begin{tabular}{|c|c|c|c|c|c|c|}
\hline Environmental Variable & $\mathrm{PC} 1$ & $\mathrm{PC} 2$ & $\mathrm{PC} 3$ & $\mathrm{PC} 4$ & PC5 & PC6 \\
\hline Elevation 300-500 m & 0.866 & & & & & \\
\hline Elevation 0-300 m & 0.847 & & & & & \\
\hline Elevation 500-700 m & 0.835 & & & & & \\
\hline Orchard & 0.738 & & & & & \\
\hline Built-up & -0.720 & & & & & \\
\hline Elevation $>2000 \mathrm{~m}$ & & 0.908 & & & & \\
\hline Open land & & 0.901 & & & & \\
\hline Rice Field & & 0.674 & & & & \\
\hline Elevation 700-1 $000 \mathrm{~m}$ & & & 0.803 & & & \\
\hline Elevation $1000-1500 \mathrm{~m}$ & & & 0.798 & & & \\
\hline Elevation $1500-2000 \mathrm{~m}$ & & & 0.686 & & & \\
\hline Shrub & & & 0.525 & & & \\
\hline Water body & & & -0.511 & & & \\
\hline Slope $>45 \%$ & & & & -0.706 & & \\
\hline Forest & & & & -0.617 & & \\
\hline Savanna & & & & 0.522 & & \\
\hline Slope $8-15 \%$ & & & & & 0.834 & \\
\hline Slope $0-3 \%$ & & & & & 0.525 & \\
\hline Slope 3-8\% & & & & & 0.509 & \\
\hline Slope $15-25 \%$ & & & & & & 0.880 \\
\hline Slope $25-45 \%$ & & & & & & -0.710 \\
\hline Eigenvalue & 5.809 & 2.973 & 1.941 & 1.901 & 1.393 & 1.094 \\
\hline Variance $(\%)$ & 27.66 & 14.159 & 9.243 & 9.052 & 6.635 & 5.211 \\
\hline Cumulative (\%) & 27.66 & 41.819 & 51.062 & 60.114 & 66.749 & 71.96 \\
\hline
\end{tabular}

Note: Principal Component (PC); rotation method: varimax with kaiser normalization

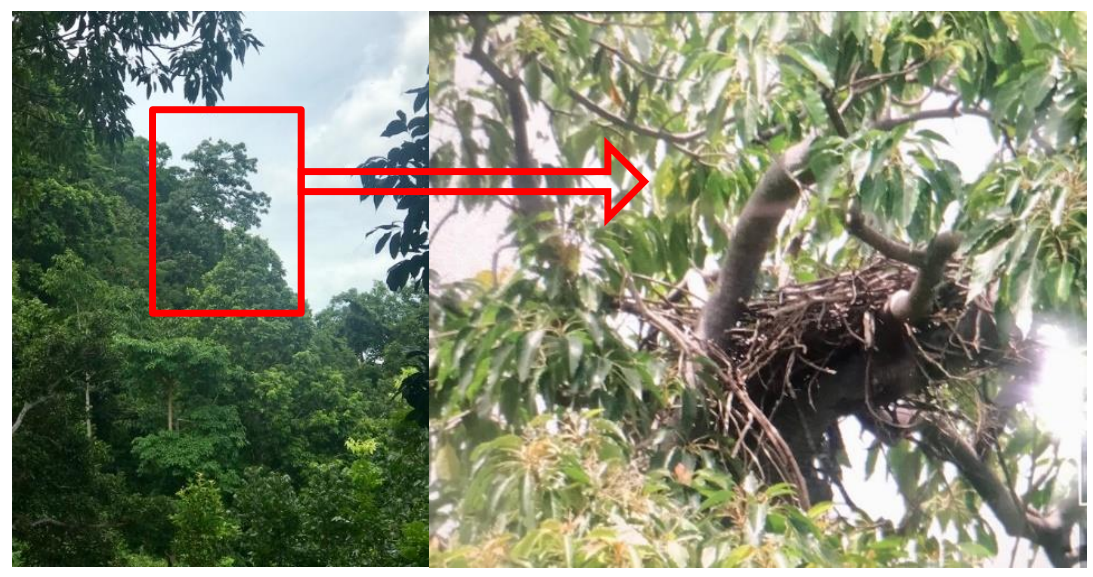

(a)

(b)

Figure 3 Pulai (Alstonia scholaris) as nest tree located in steep area in Wolojita Resort, buffer zone of Kelimutu National Park (a), FHE nest condition (b); Source: field survey 
The first to fourth principal components (PC1, PC2, PC3, PC4) indicate habitat requirements of FHE for hunting, perching, and breeding activities. Habitat requirements for hunting and perching areas are vegetated areas with the presence of trees in various land cover types. This result is aligned with the observation in Ruteng Nature Recreation Area and Mbeliling Forest, FHEs often seen perching (65\%) than flying (35\%) (Suparman, 2012). Meanwhile, slope and elevation are physical variables that shape the topography of an area which are essential to generate the thermal wind needed by raptors for flight activities such as gliding and soaring (Syartinilia et al., 2015, 2020). Careau et al. (2006) also said that solar radiation and variations in the contours of the landform could affect soaring and gliding activities that require wind. This fact is supported by the results of the main components in PC5 and PC6.

Results of this study will be used as recommendation for developing conservation strategies and action for FHE. Especially, the spatial distribution of FHE habitat can be used as a recommendation to increase the population of FHE species by $10 \%$ through habitat monitoring and conservation activities. There is still limited information about FHE, the results of this study can be used as basic data to conduct further research on spatial distribution modeling so that predictions of the suitability of FHE habitats can be obtained on all islands that are FHE habitats. Due to the high threat of FHE from human activities such as poaching and habitat destruction, public awareness about the FHE is very important in mitigation efforts. This activity can involve multistakeholders such as NGOs, the government, the community, and the private sector. Through environmental education, they are increasingly aware that the FHE ecosystem is highly dependent on the community.

\section{CONCLUSION}

The habitat patches that have been identified are eight patches with a total area of $1132 \mathrm{~km}^{2}$, spread over the island of Flores. FHE habitat patches were dominated by forest cover (47\%), 1 000-1 500 masl (29\%), and slope of $25-45 \%(35 \%)$. The landscape characteristics of the FHE habitat are interpreted through the six principal components of the habitat patch characteristics. Habitat characteristics of FHE describe its requirement for nesting and hunting activities for principal components 1 to 4 (PC1, PC2, PC3, PC4), while for flight activity related to principal components 5 and 6 (PC5 and PC6). Results of this study will be supported as baseline information for developing conservation strategies and action for FHE.

\section{REFERENCES}

BirdLife International. 2018. Nisaetus floris (Amended Version of 2017 Assessment) [Internet]. [Downloaded 2020 March 23]. Available at: http://dx.doi.org/10.2305/IUCN.UK.20173.RLTS.T22732096A125448523.en.

Careau V, Therrien J-P, Porras P, Thomas D, Bildstein K. 2006. Soaring and gliding flight of migrating broadwinged hawks: Behavior inn the nearctic and neotropics compared. The Wilson Journal of Ornithology. 118(4): 471-477.

Coates BJ, Bishop KD. 1997. A guide to the birds of Wallacea. Australia (AU): Dove, Alderley.

Ferguson-Lees J, Christie DA. 2001. Raptors of the World. London (GB): Christopher Helm.

Gjershaug JO, Kwaloy K, Rov N, Prawiradilaga DM, Suparman U, Rahman Z. 2004. The taxonomic status of the flores hawk eangle spizaetus floris. Forktail. 20: 55-61.

Kolodzinski JJ, Tannenbaum LV, Osborn DA, Conner MC, Ford WM, Miller KV. 2010. Effects of GPS sampling intensity on home range analysis. Proc Annu Conf Southeast Assoc Fish And Wildl Agencies. 64: 13-17.

Raharjaningtrah W, Rahman Z. 2004. Study on the distribution, habitat and ecology of flores hawk-eagle spizaetus cirrhatus floris in Lombok, Sumbawa, Flores, Komodo and Rinca Islands, Nusa Tenggara, Indonesia. Annual Report of Pro Nature Fund. 13(1): 177-191.

Syartinilia, Tsuyuki S. 2008. GIS-based modelling of Javan Hawk-Eagle distribution using logistic and autologistic regression models. Biological Conservation. 141: 756-769. 
Syartinilia, Makalew ADN, Mulyani YA, Higuchi H. 2015. Landscape characteristics of wintering habitats used by oriental honey-buzzards in Borneo derived from satellite tracking data. Landscape and Ecological Engineering. 11: 61-71. doi: https://doi.org/10.1007/s11355-013-0237-4.

Syartinilia, Rafael RN, Higuchi H. 2020. Perilaku migrasi Sikep-Madu Asia dalam pemanfaatan lanskap di Flores bagian timur, Indonesia berdasarkan data satellite-tracking. JPSL. 10(3): 479-488. doi: http://dx.doi.org/10.29244/jpsl.10.3.479-488.

Suparman U. 2012. Final Report Distribution, Population and Ecological Aspect of Flores Hawk-Eagle Nisaetus Floris in and Around Flores Island, East Nusa Tenggara, Indonesia. West Java (ID): Raptor Conservation Society.

Trainor C, Lesmana D. 2000. Exploding Volcanoes, Unique Birds, Gigantic Rats and Elegant Ikat: Identifying Sites of International Biodiversity Significance on Flores, Nusa Tenggara. Bogor (ID): PKA/Birdlife/WWF. Report No. 11:269p.

van Balen S, Nijman V, So zer R. 2001. Conservation of the endemic Javan Hawk-Eagle Spizaetus bartelsi Stresemann, 1924 (Aves: Falconiformes): Density, age-structure and population numbers. Contributions to Zoology. 70: 161-173.

Verhoeye J, Holmes D. 1998. The bird of the island of Flores-a review. Kukila. 10: 3-59. doi: http://kukila.org/index.php/KKL/article/view/278.

Wells DR. 1985. The forest avifauna of Western Malesia and its conservation. In: Diamond AW, Lovejoy TE, editor. Conservation of Tropical Forest Bird, ICBP Technical Publication No. 4. London (GB): International Council for Bird Preservation. p 213-232. 